\title{
MAGNETICALLY MODIFIED SUGARCANE BAGASSE DISORDERED CARBON AS A CADMIUM REMOVAL AGENT IN WATER
}

\author{
IZZATY SYAHIRAH BAHARUdiN ${ }^{1}$, NORAINI MOHAMED NOOR ${ }^{2 *}$, \\ EzZAT CHAN ABDUllaH ${ }^{1}$, RAIHAN OTHMAN ${ }^{2}$ AND \\ MUbARAK NASIBAB MUJAWAR ${ }^{3}$ \\ ${ }^{I}$ Malaysia - Japan International Institute of Technology, \\ Universiti Teknologi Malaysia, Jalan Semarak, 54100 Kuala Lumpur, Malaysia \\ ${ }^{2}$ Science in Engineering Department, Kulliyyah of Engineering, \\ International Islamic University Malaysia, \\ Jalan Gombak, 53100 Kuala Lumpur, Malaysia \\ ${ }^{3}$ Department of Chemical Engineering, Curtin University, \\ Sarawak Campus CDT 250, 98009 Miri, Sarawak, Malaysia \\ "Corresponding author: norainimnoor@iium.edu.my
}

(Received: $2^{\text {nd }}$ February 2021; Accepted: $27^{\text {th }}$ March 2021; Published on-line: $4^{\text {th }}$ January 2022)

\begin{abstract}
Heavy metals are hazardous to health at certain levels. Currently, heavy metals are removed by physicochemical treatments, such as adsorption, flotation, and electrochemical deposition, and also biological treatments, such as algal biofilm reactor and anaerobic ammonium oxidation. In this study, magnetic biochar was produced to enhance the effectiveness and performance of the adsorbent for heavy metal removal. This study aimed to synthesise high-performance magnetic biochar, to determine the optimum parameters and conditions for high yield of magnetic biochar and high removal of cadmium $\left(\mathrm{Cd}^{2+}\right)$ from aqueous solution, and to determine the adsorption kinetics and isotherms for $\mathrm{Cd}^{2+}$ removal. Nickel oxide (NiO)-impregnated sugarcane bagasse was subjected to slow pyrolysis to produce magnetic biochar. The impregnated metal, pyrolysis temperature, and pyrolysis time were varied to determine the optimum parameters and conditions to produce high-performance magnetic biochar. The removal of $\mathrm{Cd}^{2+}$ from aqueous solution and batch adsorption study were conducted. The synthesised magnetic biochar was characterised using field-emission scanning electron microscopy (FESEM), energy dispersive X-ray (EDX), X-ray diffraction (XRD), Brunauer-Emmett-Teller (BET) surface area, Fourier transform infrared (FTIR), and vibrating sample magnetometer (VSM). The adsorption data agreed well with the pseudo-second-order model and followed the Langmuir isotherm model. This study achieved $88.47 \%$ removal efficiency of $\mathrm{Cd}^{2+}$ from aqueous solution. Thus, the removal of this heavy metal as a human carcinogen reduces the hazardous effects on human health and reduces the toxicity in the environment.
\end{abstract}

ABSTRAK: Logam berat adalah berbahaya bagi kesihatan di peringkat tertentu. Pada masa ini, logam berat disingkirkan melalui rawatan fizikokimia, seperti penyerapan, pengapungan, dan deposit elektrokimia, dan rawatan biologikal, seperti reaktor biofilem alga dan oksidasi ammonium anerobik. Kajian ini menghasilkan biochar magnetik bagi meningkatkan keberkesanan dan prestasi penyerapan penyingkiran logam berat. Kajian ini bertujuan bagi mengsintesis biochar magnetik pada prestasi tinggi, bagi menghasilkan parameter optimum dan keadaan pengeluaran tinggi biochar magnetik dan penyingkiran tinggi kadmium $\left(\mathrm{Cd}^{2+}\right)$ daripada larutan akues, dan bagi mendapatkan penyerapan kinetik dan isoterma penyingkiran $\mathrm{Cd}^{2+}$. Nikel oksida $(\mathrm{NiO})$-impregnat hampas tebu adalah 
berdasarkan pirolisis perlahan bagi menghasilkan biochar magnetik. Logam yang terimpregnat, suhu pirolisis dan tempoh pirolisis dipelbagaikan bagi mendapatkan parameter optimum dan keadaan bagi menghasilkan biochar magnetik berprestasi-tinggi. Penyingkiran $\mathrm{Cd}^{2+}$ daripada larutan akues dan kajian penyerapan berkumpulan telah dibuat. Biochar magnetik yang disentisis diklasifikasikan menggunakan mikroskopi elektron imbasan medan-pancaran (FESEM), tenaga sebaran X-ray (EDX), pembelauan X-ray (XRD), kawasan permukaan Brunauer-Emmett-Teller (BET), Penjelmaan Fourier inframerah (FTIR), dan sampel getaran magnetometer (VSM). Data penyerapan menunjukkan persetujuan dengan model aturan-kedua-pseudo dan mengikuti model isoterma Langmuir. Kajian ini mencapai $88.47 \%$ keberkesanan penyingkiran $\mathrm{Cd}^{2+}$ daripada larutan akues. Oleh itu, penyingkiran logam berat ini sebagai karsinogen manusia mengurangkan kesan teruk pada kesihatan manusia dan pengurangan toksik pada alam sekitar.

\section{KEYWORDS: biomass; heavy metal removal; magnetic biochar}

\section{INTRODUCTION}

Heavy metals are hazardous to health at certain concentrations in water. In order to meet the discharge requirements, lead, mercury, silver, chromium, cadmium, zinc, nickel, and tin are heavy metals that need to be removed from wastewater until specific allowable concentrations are achieved. These heavy metals cause serious health risks and affect the environment negatively [1,2]. The treatment of water containing heavy metals is important to reduce health risks [2]. Wastewater with high concentrations of heavy metals is hazardous to humans and the environment. Wastewater treatment is vital in providing a sustainable and safe environment. Various treatment methods have been studied in the past decade. Adsorbents from different biomass types, such as magnetic biochar, can be used for heavy metal removal from wastewater.

Studies on magnetic biochar have attracted attention as the adsorbent possesses high adsorption capability to remove heavy metals from wastewater. Moreover, the removal performance of magnetic biochar is relatively higher than biochar. Magnetic biochar can be produced from biomass sources, such as pine sawdust, palm kernel shell, cottonwood, and pineapples $[1,3-5,6]$. Several methods are available to synthesise magnetic biochar, but the most used method is pyrolysis, which is the burning of a sample in the absence of oxygen.

Cadmium is a human carcinogen, which can cause cancer and lead to death [7]. The main cause of death in 2012 was cancer, which is mainly due to genomic instability [8,9]. Other than that, the inhalation of high levels of cadmium can severely affect lungs [7]. Furthermore, consuming high levels of cadmium can cause stomach pain, resulting in diarrhoea and vomiting [7]. Prolonged exposure to cadmium, even at lower concentrations, can also lead to lung damage, fragile bones, and kidney disease [7].

Many studies have focused on wastewater treatment, including physicochemical treatment, and there is a growing interest in biological treatment. Several physicochemical treatment methods have been studied and are currently used, such as electrooxidation, chemical precipitation, adsorption, flotation, electrochemical deposition, and shales from coal mines [10-12]. Meanwhile, biological treatment methods include anaerobic ammonium oxidation, sequencing batch biofilter reactor, algal biofilm reactor, natural biofiltration, and photo-anaerobic membrane bioreactor have been studied [13-17].

Activated carbon is preferred for heavy metal removal, which becomes one of the most popular adsorbents in the wastewater industry [18]. However, high-quality activated 
carbon is more expensive and cost-inefficient [18]. Low-cost adsorbents have been introduced as alternatives to the expensive activated carbon [18]. These include adsorbents from natural materials and waste products, such as industrial by-products and modified agricultural and biological wastes [12]. Among examples of low-cost adsorbents are natural materials (e.g., chitosan, zeolites, and clay), waste products (e.g., coal, fly ash, and oxides), and biosorption products (e.g., hazelnut shells, rice husk, and pecan shells) $[12,18]$. These adsorbents are inexpensive and cost-efficient due to their availability in large quantities.

Therefore, in this study, magnetic biochar produced from modified agriculture and biological waste was used to remove cadmium in wastewater. The study of magnetic biochar for heavy metal removal from wastewater is new in Malaysia. Sugarcane bagasse was selected as the biomass source in this study because this waste material is usually discarded in Malaysia. Hence, sugarcane bagasse is easy to obtain and cost-effective. The waste also has favourable physicochemical characteristics that can assist in wastewater treatment. Chemical modification and impregnation with metals on sugarcane bagasse through slow pyrolysis can enhance the effectiveness and performance of the adsorbent.

Besides food, sugarcane is also a major source of bioethanol production that is widely used to replace gasoline in several countries, including Brazil. However, there is an issue of using food as a biomass source due to the competition between energy and food [19]. Sugar is produced from either sugar beet or sugarcane [19]. Various by-products are produced during the process, such as molasses, bagasse, pressmud, lime sludge, and beet pulp, and these by-products are renewable raw materials [19]. Therefore, these byproducts are preferred as biomass sources to avoid fuel and food competition. In Mexico, a study was conducted to simulate the potential of sugarcane and blue agave bagasse in bioethanol production by replacing food with biomass sources [20].

Several studies involving magnetic biochar as an effective heavy metal adsorbent have been conducted. Until now, several modifications have been made in various studies to improve the properties of biochar, primarily to enhance its adsorption properties for better performance. Moreover, the number of studies on sugarcane bagasse adsorbent and magnetic adsorbent has been growing since 2007. However, the studies were more favourable towards magnetic absorbent, except in 2015, where the studies on sugarcane bagasse as absorbent were higher than magnetic absorbent.

\section{MATERIALS AND METHODS}

\subsection{Materials}

Sugarcane bagasse was obtained directly from the juice stall, where the bagasse is the solid waste from the mechanical extraction of sugarcane. First, the raw sugarcane bagasse was air-dried and crushed to obtain smaller-sized biomass. The crushed bagasse was washed thrice using tap water. Then, this sample was oven-dried for $24 \mathrm{~h}$ at $70{ }^{\circ} \mathrm{C}$ and left in room temperature drying rack for 1 week. This study used a synthetic wastewater sample prepared with a similar concentration of pure $\mathrm{Cd}^{2+}$ instead of industrial wastewater to evaluate the removal efficiency of $\mathrm{Cd}^{2+}$ using magnetic biochar. This synthetic wastewater sample can help simulate the real industrial wastewater behaviour.

In this work, sugarcane bagasse was impregnated with three types of nickel metals \{nickel oxide $(\mathrm{NiO})$, nickel chloride $\left(\mathrm{NiCl}_{2}\right)$, and nickel sulfate $\left(\mathrm{NiSO}_{4}\right)$ \}. The impregnation produced sugarcane bagasse magnetic biochar, which was later used for $\mathrm{Cd}^{2+}$ adsorption in aqueous solution. 


\subsection{Synthesis of Magnetic Biochar}

The dried sugarcane bagasse was magnetised by the impregnation of metal salts on the biomass surface. The metal salt solutions of $\mathrm{NiO}, \mathrm{NiCl}_{2}$, and $\mathrm{NiSO}_{4}$ were prepared and biomass was immersed in the solutions with the metal salt-to-biomass ratio of $0.45: 1$, where the ratio was kept constant throughout the experiment. Next, the immersed biomass was placed in a shaker for $1 \mathrm{~h}$ at $170 \mathrm{rpm}$. After completion, the sample was filtered and oven-dried at $70{ }^{\circ} \mathrm{C}$ for $24 \mathrm{~h}$ prior to slow pyrolysis. The ratio of metal salt per biomass was maintained and the holding time was 10 and $20 \mathrm{~min}$. Approximately 5 and $10 \mathrm{~g}$ of the impregnated sugarcane bagasse were weighed for the experiments with pyrolysis time of 10 and $20 \mathrm{~min}$, respectively.

Magnetic biochar was synthesised in oxygen-free conditions through slow pyrolysis in a WiseTherm muffle furnace. A vacuum pump was used for degassing prior to pyrolysis to achieve oxygen-free conditions. Various temperatures ranging from 400 to $700{ }^{\circ} \mathrm{C}(400$, $450,500,550,600,650$, and $700{ }^{\circ} \mathrm{C}$ ) were used for the determination of optimum temperature to produce magnetic biochar with high adsorption capacity at $25^{\circ} \mathrm{C} / \mathrm{min}$ heating rate. This temperature range was selected because the pyrolysis working temperature is between 400 and $700{ }^{\circ} \mathrm{C}$. Sugarcane bagasse cannot be magnetised when the temperature is lower than $400{ }^{\circ} \mathrm{C}$, where carbonisation occurs at this temperature range. Similarly, gasification occurs when the temperature exceeds $700{ }^{\circ} \mathrm{C}$.

After pyrolysis, the magnetic biochar was cooled to room temperature before it was crushed to smaller size. Next, the crushed magnetic biochar was rinsed with distilled water several times until it reached the neutral state. Finally, the magnetic biochar was ovendried and stored in an airtight plastic container prior to characterisation.

\subsection{Characterisation of Magnetic Biochar}

Prior to adsorption, magnetic biochar was characterised using Brunauer-EmmettTeller (BET) surface area, field-emission scanning electron microscopy (FESEM), X-ray diffraction (XRD), Fourier transform infrared (FTIR), and vibrating sample magnetometer (VSM). After $\mathrm{Cd}^{2+}$ removal from wastewater, only FESEM, XRD, and FTIR were conducted to characterise the samples. BET analysis was performed to calculate the surface area of magnetic biochar. The optimum condition to produce magnetic biochar was analysed using FTIR to determine the surface functional groups before and after the adsorption of $\mathrm{Cd}^{2+}$. FESEM was used to observe the porosity and structure of the sample's surface after synthesising magnetic biochar. This characterisation is also required to observe the condition of magnetic biochar after $\mathrm{Cd}^{2+}$ adsorption from synthetic wastewater. The phase identification and structure of magnetic biochar before and after adsorption were studied using XRD. Meanwhile, VSM was applied to measure and determine the magnetic properties of the synthesised magnetic biochar.

\subsection{Cadmium Adsorption}

About $0.3 \mathrm{~g}$ of each sample was weighed and synthetic wastewater solution with 20 ppm of cadmium concentration was prepared. The samples were added into capillary tubes filled with $10 \mathrm{ml}$ of cadmium solution. The samples in the capillary tubes were agitated at $200 \mathrm{rpm}$ for $1 \mathrm{~h}$ using an incubator shaker (IKA KS $3000 \mathrm{i}$ control). After completion, the samples were filtered and $10 \mathrm{ml}$ of the solution was collected in smaller capillary tubes. Atomic absorption spectroscopy (AAS) was utilised to analyse the samples. The optimum time and temperature were selected for the sample with the highest cadmium removal. 


\subsection{Batch Adsorption Study}

After obtaining the AAS results, the sample with the optimum time and temperature was selected to conduct a batch adsorption study. Cadmium solutions of 20, 40, 60, 80, and $100 \mathrm{ppm}$ were prepared and each solution was filled in a conical flask. Then, $0.6 \mathrm{~g}$ of the selected sample was added into each conical flask containing $200 \mathrm{ml}$ solution.

\section{RESULTS AND DISCUSSION}

\subsection{Magnetic Biochar Yield and $\mathrm{Cd}^{2+}$ Removal Percentage of Magnetic Biochar}

The yield of magnetic biochar was determined by weighing the magnetic biochar before and after pyrolysis (Eq. 1). Meanwhile, the $\mathrm{Cd}^{2+}$ removal percentage was determined by measuring the concentration of $\mathrm{Cd}^{2+}$ after adsorption using AAS (Eq. 2).

$$
\begin{aligned}
& \% \text { magnetic biochar yield }=\frac{\left(\text { Weight }_{\text {after }}-\text { Weight }_{\text {before }}\right)}{\text { Weight }_{\text {before }}} \times 100 \% \\
& \% \text { removal }=\frac{\left(\text { Concentration }_{\text {Cd }^{2+}, \text { after }}-\text { Concentration }_{\left.C d^{2+}{ }_{, \text {before }}\right)}\right)}{\text { Concentration }_{\text {Cd }^{2+}{ }_{, \text {before }}}} \times 100 \%
\end{aligned}
$$

Figure 1a illustrates the yields of magnetic biochar over pyrolysis temperature using different types of sugarcane bagasse impregnated for $10 \mathrm{~min}$. NiO-impregnated sugarcane bagasse showed the highest yield $(46.5 \%)$ compared to other metals at $400{ }^{\circ} \mathrm{C}$, followed by $\mathrm{NiO}$-impregnated sugarcane bagasse at $500{ }^{\circ} \mathrm{C}$ with $42.53 \%$ yield. The finding clearly shows that a higher pyrolysis temperature will result in a lower yield of magnetic biochar. The percentage of yield decreased with pyrolysis temperature. At elevated temperatures from 400 to $600{ }^{\circ} \mathrm{C}$, biomass decomposed and produced lower magnetic biochar yields, nearly $50 \%$ reduction from the initial yield. This result suggests that most of the volatile matter in sugarcane bagasse decomposed at higher temperatures, leaving a small amount of magnetic biochar with high carbon content. On the other hand, slow heating exposed sugarcane bagasse to heat for a longer time, allowing more volatile matter to decompose and form more surface pores [21].

According to Fig. 1b, $\mathrm{NiSO}_{4}$-impregnated sugarcane bagasse achieved the highest yield of $36.03 \%$ at $400{ }^{\circ} \mathrm{C}$. From the figure, different anions of metal salts affected the percentage of yield produced, indicating the changes in the primary degradation of the biomass.

Figure $2 \mathrm{a}$ presents the graph of $\mathrm{Cd}^{2+}$ removal percentage versus temperature at $10 \mathrm{~min}$ of pyrolysis time. NiO-impregnated magnetic biochar demonstrated the highest $\mathrm{Cd}^{2+}$ removal efficiency of $88.57 \%$ at $500{ }^{\circ} \mathrm{C}$, followed by $\mathrm{NiSO}_{4}$-impregnated magnetic biochar $(88.55 \%)$ at $400{ }^{\circ} \mathrm{C}$ and $\mathrm{NiCl}_{2}$-impregnated magnetic biochar $(87.69 \%)$ at $500{ }^{\circ} \mathrm{C}$. The removal efficiency decreased as the impregnated magnetic biochars were heated from 400 to $500{ }^{\circ} \mathrm{C}$, except $\mathrm{NiO}$-impregnated magnetic biochar. In contrast to the impregnated magnetic biochars produced at 20 min of pyrolysis time (Fig. 2b), the removal percentage started to increase after $450{ }^{\circ} \mathrm{C}$ and decrease beyond $600{ }^{\circ} \mathrm{C}$. The reason for such behaviour is that the development of the pore structure and active sites are insufficient at high pyrolysis temperatures [22].

The best metal to be impregnated with magnetic biochar and the optimum parameters and conditions were determined from the metal-impregnated magnetic biochar producing the best yield and $\mathrm{Cd}^{2+}$ removal percentage. Therefore, NiO-impregnated magnetic biochar 
was chosen due to its high yield of $40.24 \%$ and high $\mathrm{Cd}^{2+}$ removal efficiency of $88.57 \%$ at $500{ }^{\circ} \mathrm{C}$.

(a)

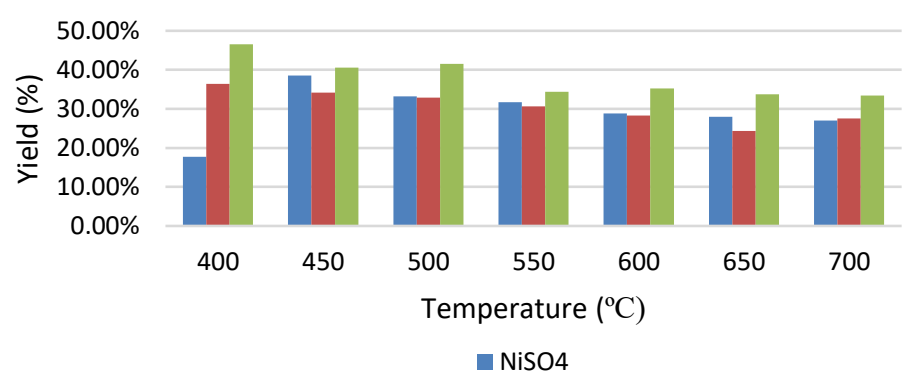

(b)

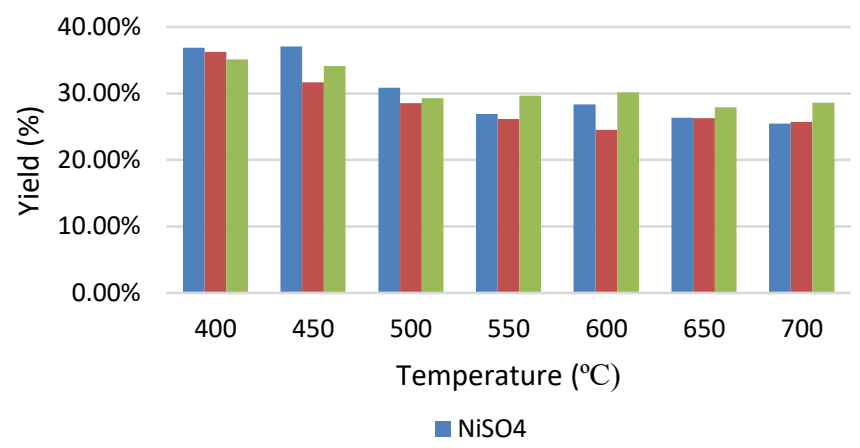

Fig. 1: Yield of magnetic biochar at (a) $10 \mathrm{~min}$ and (b) $20 \mathrm{~min}$ of pyrolysis time.

(a)

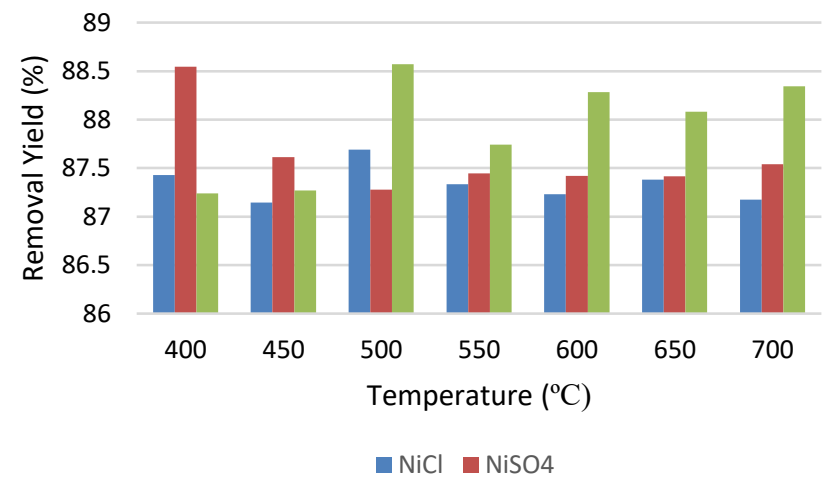

(b)

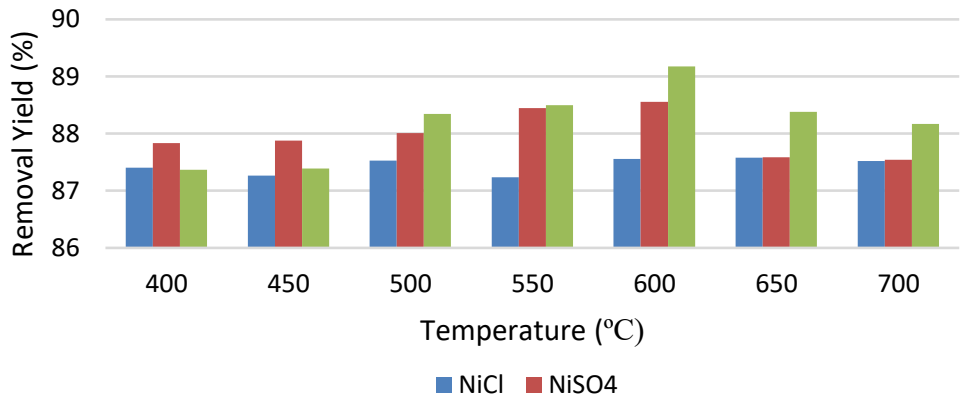

Fig. 2: $\mathrm{Cd}^{2+}$ removal percentage of magnetic biochar at (a) $10 \mathrm{~min}$ and (b) $20 \mathrm{~min}$ of pyrolysis time. 


\subsection{Characterisation of Magnetic Biochar}

\subsubsection{Field-Emission Scanning Electron Microscopy and Energy Dispersive X-ray Spectroscopy Analysis}

The surface structure of raw sugarcane bagasse and magnetic biochar was studied using FESEM. Figure 3(a-d) depict the morphology of raw sugarcane bagasse, sugarcane bagasse biochar, magnetic biochar before adsorption, and magnetic biochar after adsorption, respectively. Raw sugarcane bagasse has a more blocked and smooth surface [23], but the structure is more porous and agglomeration could be observed (Fig. 3d) after impregnation and pyrolysis of sugarcane bagasse. This finding suggests that the metals are impregnated on raw sugarcane bagasse after the synthesis process. The widening of pores could be seen from the figures, indicating the extraction of some materials, such as the dissolution of lignin and other components from the bagasse during impregnation. The loss of volatile compounds from within the particles increased gradually when the final temperature increased during heating.
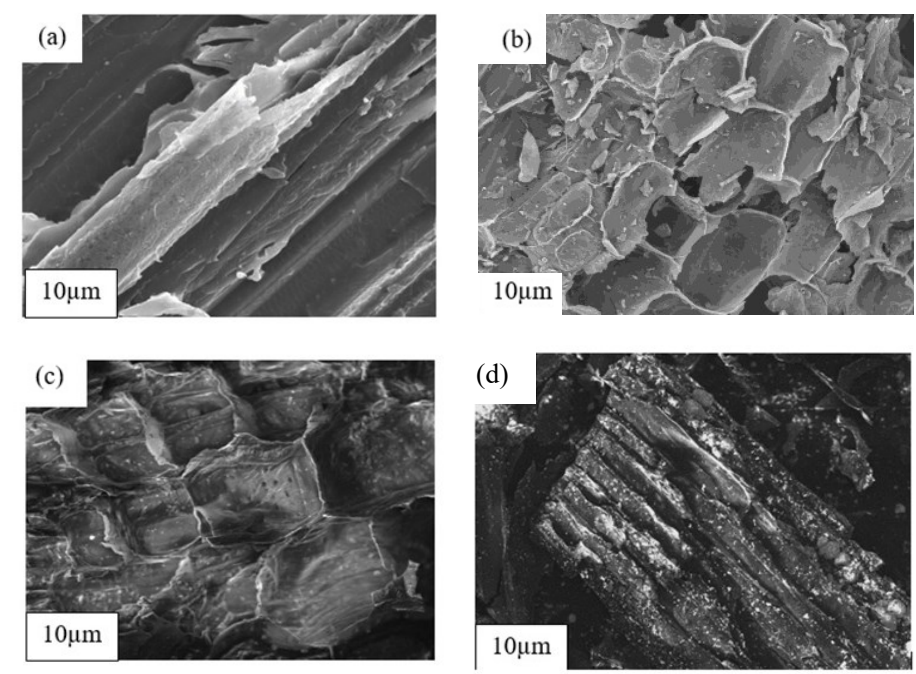

Fig. 3: Morphology of (a) raw sugarcane bagasse, (b) sugarcane bagasse biochar, (c) magnetic biochar before adsorption, and (d) magnetic biochar after adsorption.

Figure 4 presents the EDX analysis of magnetic biochar after $\mathrm{Cd}^{2+}$ adsorption, which shows the presence of cadmium element in the magnetic biochar. This analysis agrees that magnetic biochar can remove heavy metals from aqueous solution.

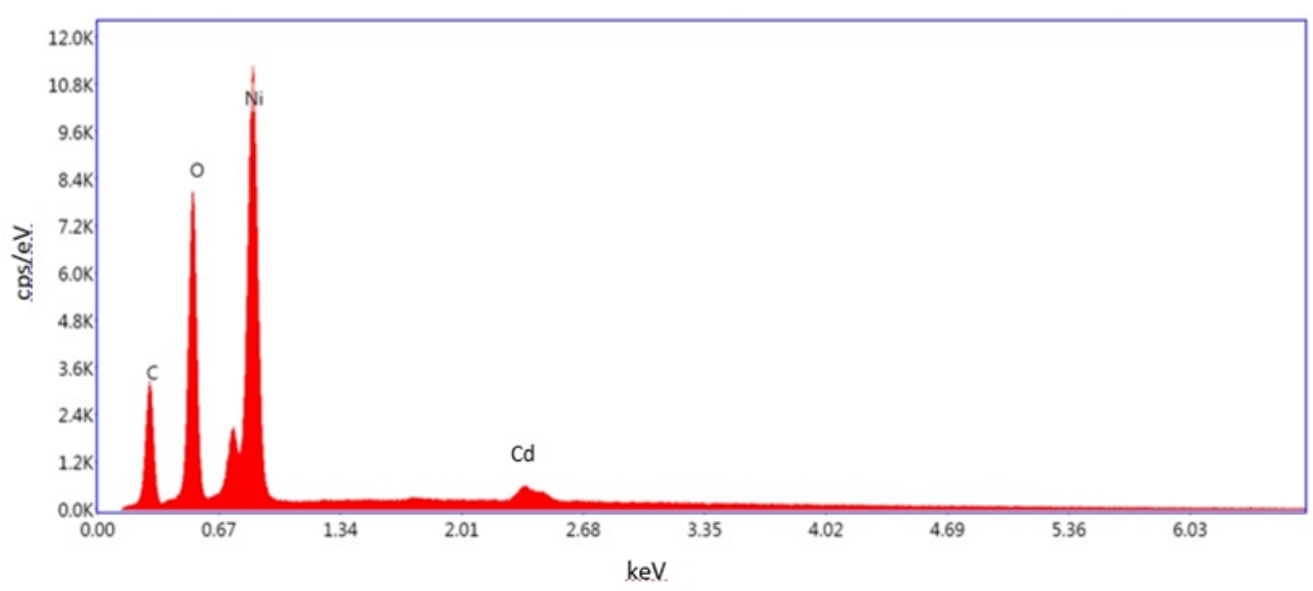

Fig. 4: EDX analysis of magnetic biochar after $\mathrm{Cd}^{2+}$ adsorption. 


\subsubsection{Vibrating Sample Magnetometer Analysis}

In this study, VSM analysis was conducted to measure the magnetisation of magnetic biochar. Figure 5 depicts the magnetic hysteresis cycles of magnetic biochar. The magnetic biochar recorded the coercive field of $163.96 \mathrm{G}$, saturation magnetisation (Ms) of $0.24093 \mathrm{emu} / \mathrm{g}$, and retentivity $(\mathrm{Mr})$ of $0.07377 \mathrm{emu} / \mathrm{g}$. Meanwhile, raw sugarcane bagasse did not give any magnetisation value.

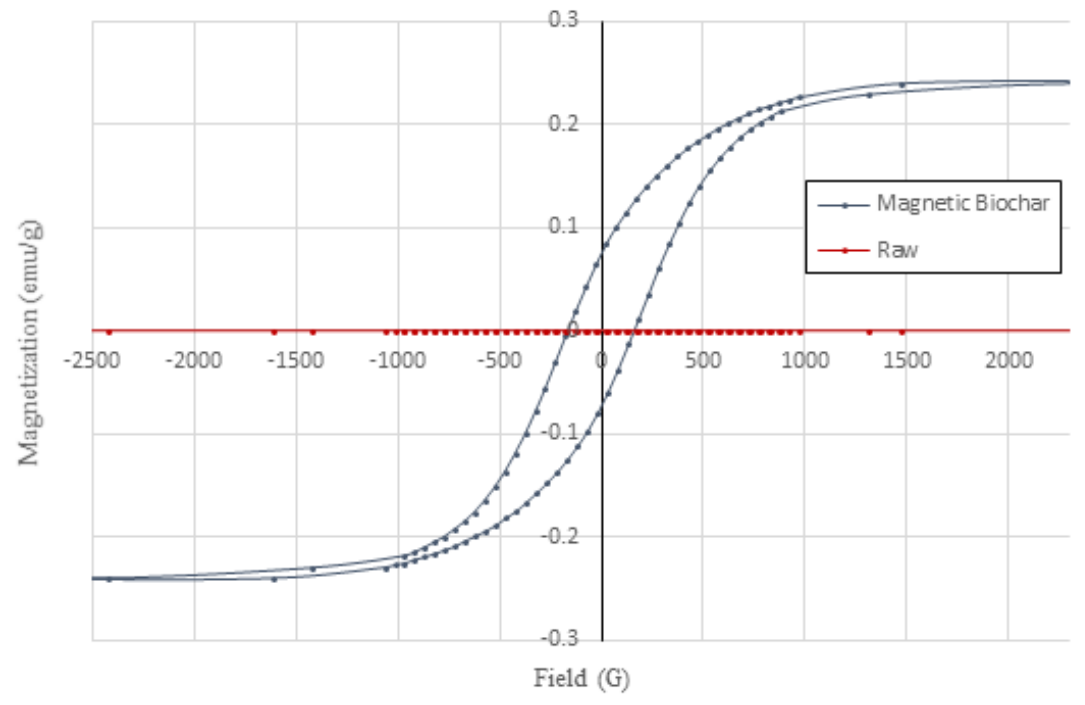

Fig. 5: Magnetic hysteresis cycles of magnetic biochar.

The magnetic hysteresis cycles prove that raw sugarcane bagasse does not have ferromagnetic properties, whereas magnetic biochar shows ferromagnetic properties. Therefore, magnetic biochar can be recovered using magnets. A magnet bar was placed outside of glass bottles containing magnetic biochar to test its magnetic separation ability (Fig. 6). This phenomenon can be considered a combination of superparamagnetic, ferromagnetic, and paramagnetic behaviours [24].

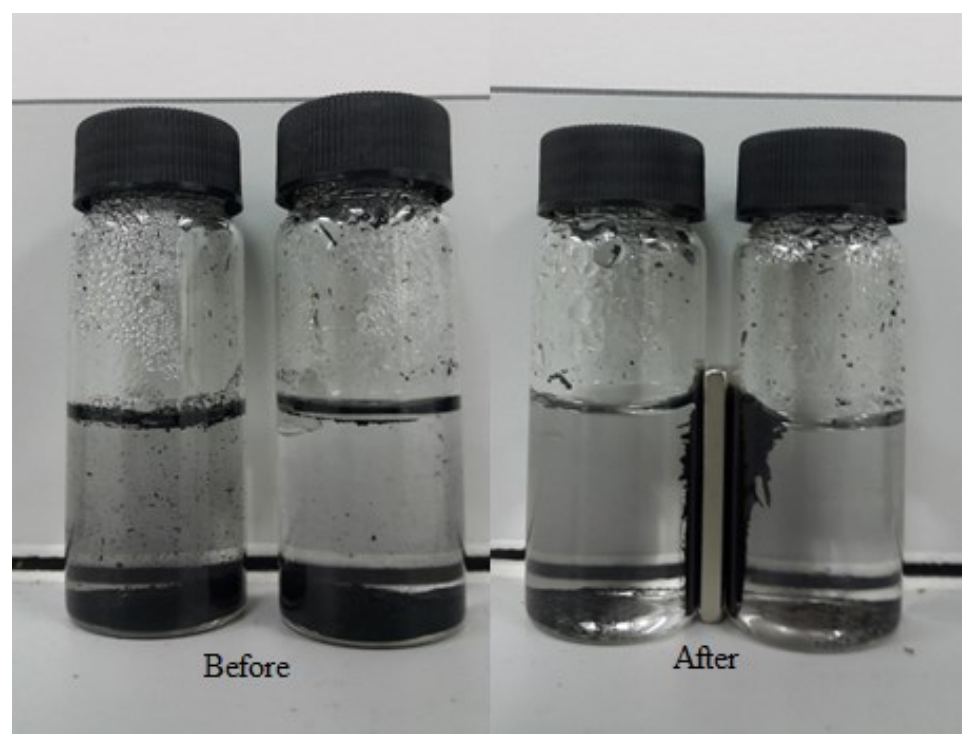

Fig. 6: Magnetic separation ability of magnetic biochar before and after putting the magnetic bar. 


\subsubsection{Fourier Transform Infrared Spectroscopy Analysis}

FTIR analysis was carried out to determine the functional groups available in raw sugarcane bagasse and magnetic biochar before and after $\mathrm{Cd}^{2+}$ adsorption. Figure $7(\mathrm{a})$ presents the FTIR spectra of raw sugarcane bagasse and Fig. 7(b) illustrates the FTIR spectra of magnetic biochar before and after $\mathrm{Cd}^{2+}$ adsorption. The spectra are different in the raw sugarcane bagasse compared to the synthesised magnetic biochar. Therefore, the internal structure of magnetic biochar and their functional groups changed during synthesis.
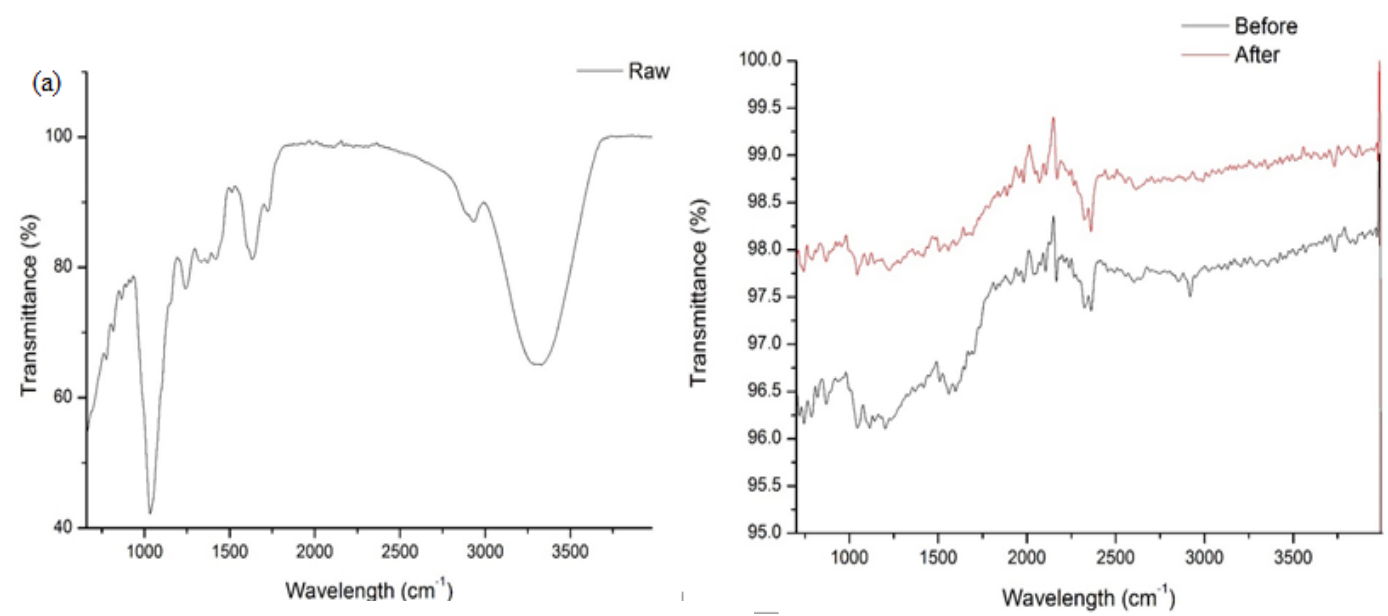

Fig. 7: FTIR spectra for (a) raw sugarcane bagasse and (b) magnetic biochar before and after $\mathrm{Cd}^{2+}$ adsorption.

Table 1 shows the possible functional groups present before $\mathrm{Cd}^{2+}$ adsorption. For the FTIR spectra before $\mathrm{Cd}^{2+}$ adsorption, there is a peak present around $2,921 \mathrm{~cm}^{-1}$, suggesting the presence of $\mathrm{CH}$ stretch. Meanwhile, the peak at $1,653 \mathrm{~cm}^{-1}$ indicates $\mathrm{C}=\mathrm{C}$ stretch, which is present due to pyrolysis. Other than that, the $\mathrm{C}-\mathrm{N}$ stretch is present at $1,041 \mathrm{~cm}^{-1}$, showing that organic compounds are present in the magnetic biochar. It is observed that these functional groups are absent after $\mathrm{Cd}^{2+}$ adsorption in aqueous solution. This finding indicates that the adsorption of heavy metals breaks the bonds of the functional groups.

Table 1: Possible functional groups of the identified peaks

\begin{tabular}{cc}
\hline Peak Position $\left(\mathbf{c m}^{-1}\right)$ & Possible Functional Group \\
\hline 2,921 & CH stretch \\
1,653 & C $=$ C stretch \\
1041 & C-N stretch \\
\hline
\end{tabular}

\subsubsection{Brunauer-Emmett-Teller Surface Area Analysis}

BET surface area analysis was conducted to calculate the surface area of raw sugarcane bagasse and magnetic biochar. Table 2 lists the surface area and porosity of raw sugarcane bagasse and magnetic biochar. The results showed higher surface area, total pore volume, and average pore diameter of magnetic biochar than raw sugarcane bagasse. This finding indicates that the pyrolysis of sugarcane bagasse to magnetic biochar increased the surface area and porosity, resulting in higher adsorption capacities. The significant improvement in the surface area and pore volume in magnetic biochar may be due to the significant increase in volatile released [25]. In addition, the NiO impregnated 
on the surface of magnetic biochar increased the surface area due to the combustion of the organic molecules trapped in the particles and recrystallization of $\mathrm{NiO}$ [26]. Therefore, magnetic biochar has higher adsorption capacity than conventional biochar or raw sugarcane bagasse.

Table 2: Main textural characteristics of raw sugarcane bagasse and magnetic biochar

\begin{tabular}{lcc}
\hline Properties & Raw Sugarcane Bagasse & Magnetic Biochar \\
\hline Specific surface area $\left(\mathrm{m}^{2} / \mathrm{g}\right)$ & 1.8058 & 10.6364 \\
Total pore volume $\left(\mathrm{cm}^{3} / \mathrm{g}\right)$ & 0.0011 & 0.03437 \\
Average pore diameter $(\mathrm{nm})$ & 2.3330 & 11.5499 \\
\hline
\end{tabular}

\subsubsection{X-Ray Diffraction Analysis}

XRD analysis was carried out to identify phase characteristics. Figure 8 illustrates the XRD patterns of magnetic biochar. The figure suggests that crystalline $\mathrm{NiO}$ formed in magnetic biochar with the highest intensity of $2 \theta=43.3302^{\circ}$ at (200) plane. Other than that, the $\mathrm{NiO}$ peaks are observed at $2 \theta=37.2722^{\circ}, 62.8562^{\circ}, 75.4142^{\circ}$, and $79.3662^{\circ}$ at (111), (220), (311), and (222) planes, respectively. The formation of Ni is also shown at the peaks around $2 \theta=44.5262^{\circ}$ and $51.9102^{\circ}$ at (111) and (200) planes, respectively.

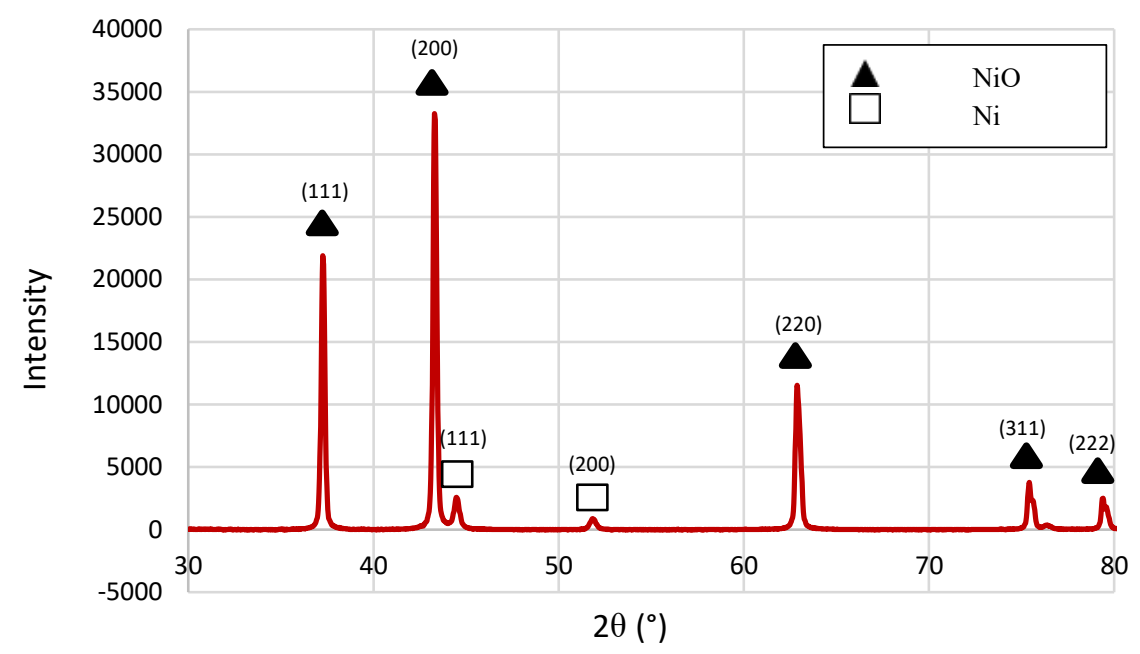

Fig. 8: XRD patterns of magnetic biochar.

At $400-500{ }^{\circ} \mathrm{C}, \mathrm{NiO}$ is reduced to metallic $\mathrm{Ni}$ as magnetic biochar most probably acts as a reducing agent [27]. The analysis shows the formation of magnetic biochar, as confirmed by the existence of $\mathrm{NiO}$ and metallic $\mathrm{Ni}$ in magnetic biochar.

\subsection{Batch Adsorption Study}

Adsorption kinetics and isotherms were examined in the batch adsorption study. According to Fig. 9, $\mathrm{Cd}^{2+}$ adsorption reached equilibrium at $120 \mathrm{~min}$. The figure also shows that the higher the concentration, the higher the amount of $\mathrm{Cd}^{2+}$ absorbed by magnetic biochar due to the increases in adsorption capacity. The increase in the mass transfer driving force where the movement of $\mathrm{Cd}^{2+}$ ion into the magnetic biochar surfaces, leading to high adsorption rates [28]. 


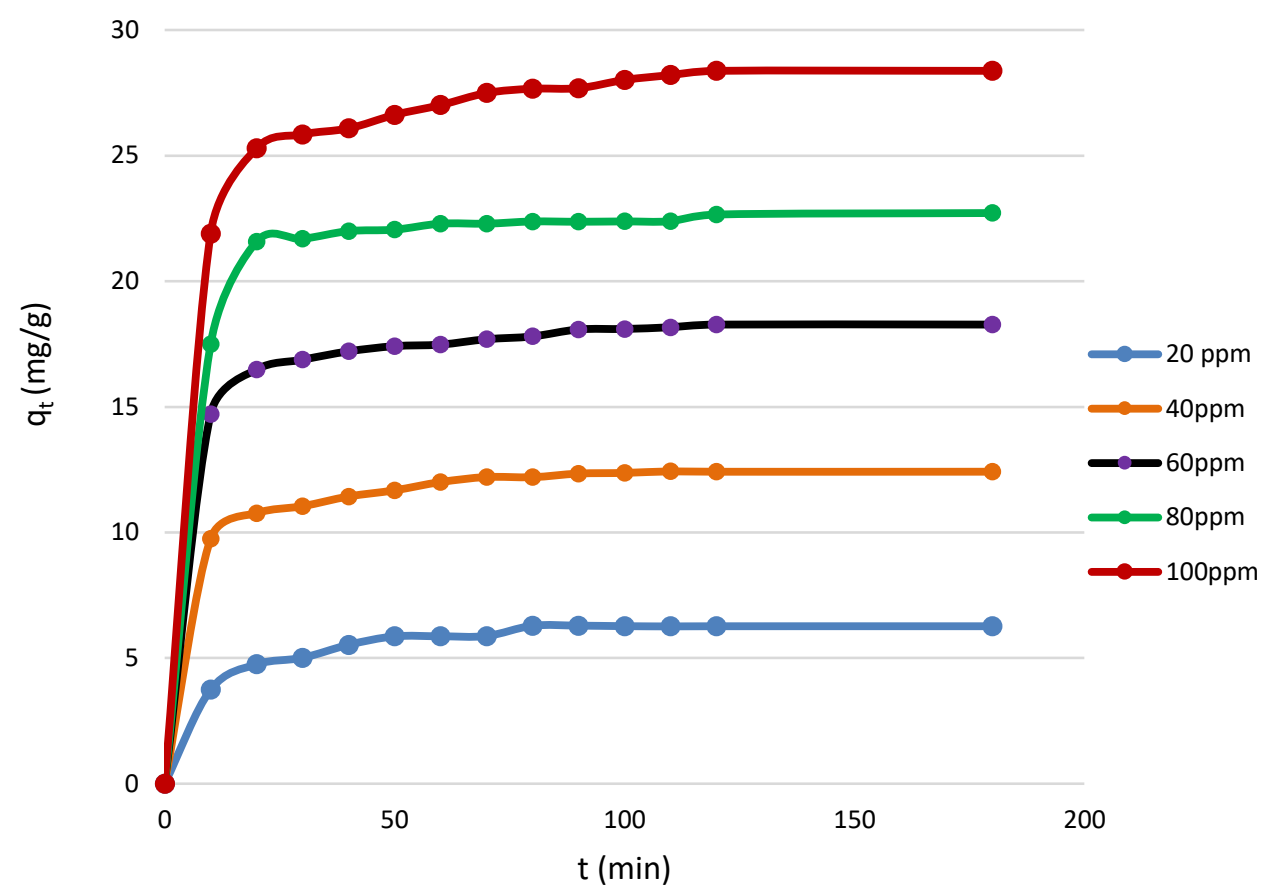

Fig. 9: Effect of time on cadmium adsorption capabilities.

\subsection{Adsorption Kinetics}

The effect of cadmium adsorption kinetics on the magnetic biochar was simulated using two mathematical models: pseudo-first-order (Eq. 3) and pseudo-second-order (Eq. 4) models. Figure $10(a, b)$ presents the adsorption kinetics for the pseudo-first-order and pseudo-second-order models, respectively, for $\mathrm{Cd}^{2+}$ adsorption on magnetic biochar.

$$
\begin{aligned}
& \ln \left(\frac{q_{e}}{q_{e}-q_{t}}\right)=k_{1} t \\
& \frac{1}{\left(q_{e} q_{t}\right)}=\frac{1}{q_{e}}+k_{2} t
\end{aligned}
$$

where:

$q_{e}=$ amount of $\mathrm{Cd}^{2+}$ adsorbed at time $t$;

$q_{t}=$ amount of $\mathrm{Cd}^{2+}$ adsorbed at equilibrium;

$k_{1}=$ pseudo-first-order rate constant; and

$k_{2}=$ pseudo-second-order rate constant.

Tables 3 and 4 tabulate the kinetic parameters of $\mathrm{Cd}^{2+}$ adsorption for pseudo-firstorder and pseudo-second-order models, respectively. The correlation coefficient $\left(\mathrm{R}^{2}\right)$ values for both kinetic models clearly show that the experimental data follow the pseudosecond-order model with $\mathrm{R}^{2} \approx 1$. Therefore, the pseudo-first-order model could not describe the adsorption kinetics of this study. It is assumed that the amount of $\mathrm{Cd}^{2+}$ on the surface of magnetic biochar affects the adsorption, and the pseudo-second-order model suggests that the adsorption process is chemisorption as visualised in FTIR analysis previously, where $\mathrm{Cd}^{2+}$ adsorption in this study is due to the chemical bonds formed [1]. 
(a)

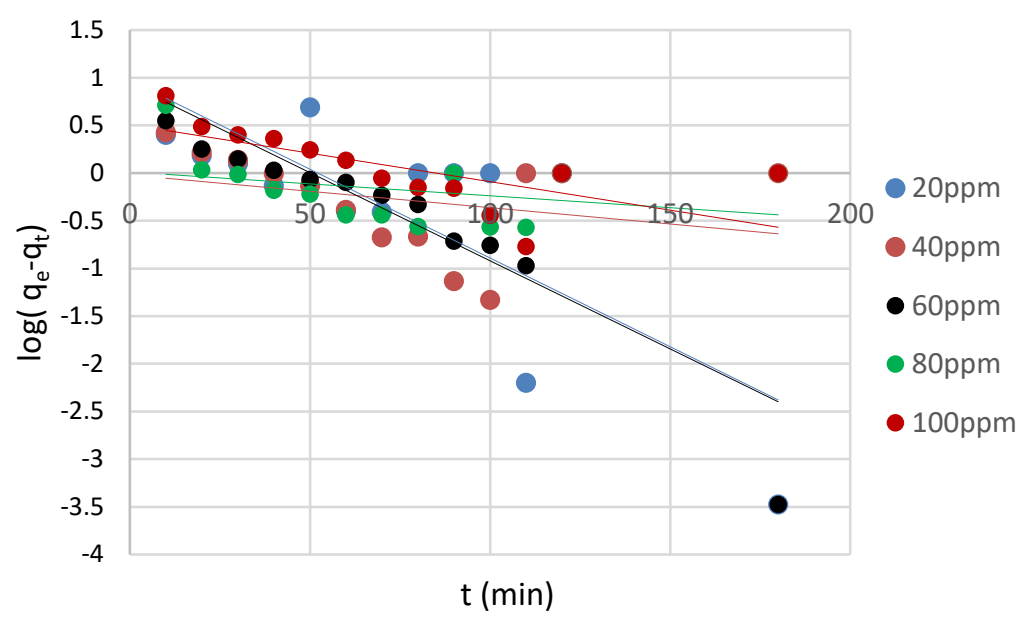

(b)

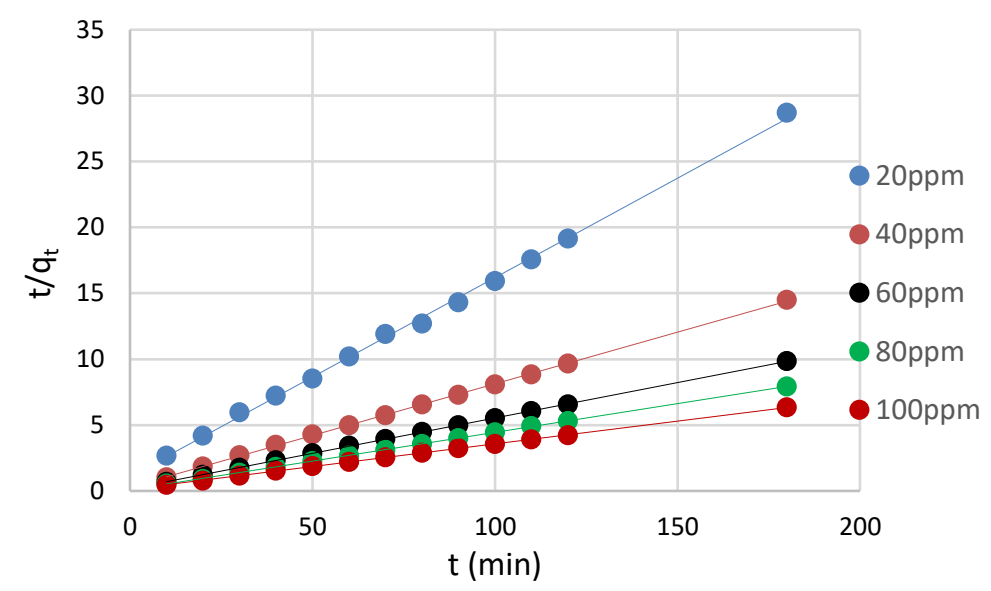

Fig. 10: (a) Pseudo-first-order and (b) pseudo-second-order models of $\mathrm{Cd}^{2+}$ adsorption.

Table 3: Kinetic parameters of $\mathrm{Cd}^{2+}$ adsorption for the pseudo-first-order model

\begin{tabular}{ccccc}
\hline $\mathbf{C}_{\mathbf{o}}(\mathbf{m g} / \mathbf{L})$ & $\mathbf{q e}_{\mathbf{e}}(\mathbf{m g} / \mathbf{g})$ & $\mathbf{k}_{\mathbf{1}}$ & $\mathbf{q}_{\mathbf{e}}$ & $\mathbf{R}^{\mathbf{2}}$ \\
\hline $\mathbf{2 0}$ & 60.2683 & -2.2364 & 0.9581 & 0.5798 \\
$\mathbf{4 0}$ & 12.4177 & 0.0451 & 0.9922 & 0.0917 \\
$\mathbf{6 0}$ & 18.2750 & -2.1395 & 0.9583 & 0.7415 \\
$\mathbf{8 0}$ & 22.6550 & 0.1145 & 0.9915 & 0.0828 \\
$\mathbf{1 0 0}$ & 28.3737 & -1.1692 & 0.9863 & 0.4615 \\
\hline
\end{tabular}

Table 4: Kinetic parameters of $\mathrm{Cd}^{2+}$ adsorption for the pseudo-second-order model

\begin{tabular}{ccccc}
\hline $\mathbf{C}_{\mathbf{o}}(\mathbf{m g} / \mathbf{L})$ & $\mathbf{q}_{\mathbf{e}}(\mathbf{m g} / \mathbf{g})$ & $\mathbf{k}_{\mathbf{2}}$ & $\mathbf{q}_{\mathbf{e}}$ & $\mathbf{R}^{\mathbf{2}}$ \\
\hline $\mathbf{2 0}$ & 60.2683 & 0.0206 & 6.6313 & 0.9986 \\
$\mathbf{4 0}$ & 12.4177 & 0.0210 & 12.7551 & 0.9998 \\
$\mathbf{6 0}$ & 18.2750 & 0.0173 & 18.6220 & 0.9999 \\
$\mathbf{8 0}$ & 22.6550 & 0.0212 & 22.9358 & 0.9999 \\
$\mathbf{1 0 0}$ & 28.3737 & 0.0091 & 28.9855 & 0.9998 \\
\hline
\end{tabular}

The kinetic parameters for the adsorption of heavy metals are insignificant because the experimental data did not fit well with the pseudo-first-order model. 


\subsection{Adsorption Isotherms}

The isotherm models studied were the Freundlich (Eq. 5) and Langmuir isotherm models (Eq. 6).

$$
\begin{aligned}
& q_{e}=\frac{Q_{m} K_{L} C_{e}}{1+K_{L} C_{e}} \\
& q_{e}=\ln K_{F}+\frac{1}{n} \ln C_{e}
\end{aligned}
$$

where:

$$
\begin{aligned}
& C_{e}=\text { concentration of solution at equilibrium; } \\
& q_{e}=\text { adsorption of } \mathrm{Cd}^{2+} \text { at equilibrium; } \\
& K_{L}=\text { Langmuir model's constant; and } \\
& K_{F}=\text { Freundlich affinity coefficient. }
\end{aligned}
$$

Both isotherm models assume different adsorption mechanics. The Freundlich isotherm model assumes the chemisorption of $\mathrm{Cd}^{2+}$ on the heterogeneous surface of magnetic biochar, while the Langmuir isotherm model describes the homogeneous surface of magnetic biochar by monolayer adsorption for $\mathrm{Cd}^{2+}$ removal. Figure 11(a,b) illustrate the Freundlich and Langmuir isotherm models for $\mathrm{Cd}^{2+}$ adsorption of this study, respectively.

(a)

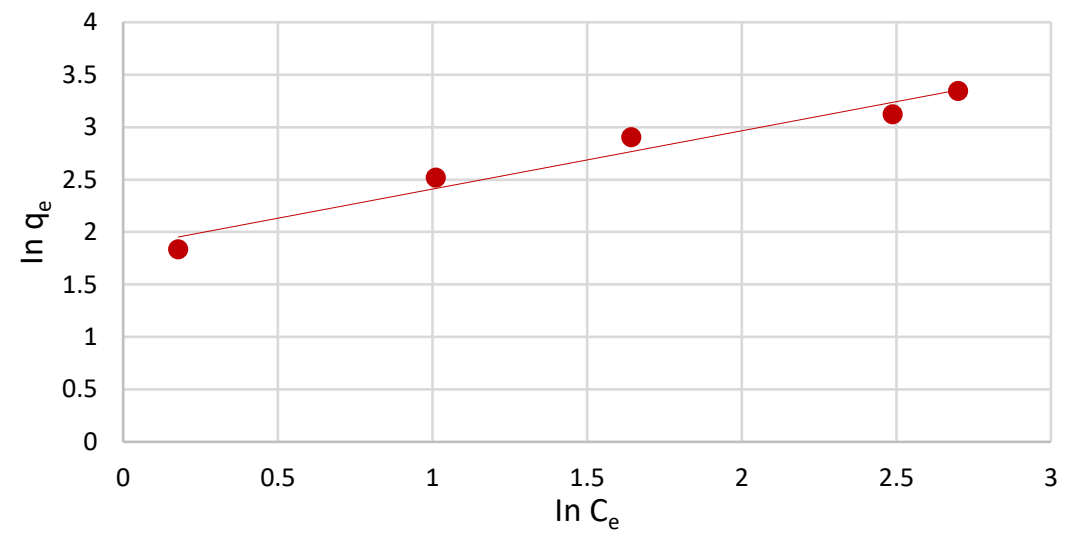

(b)

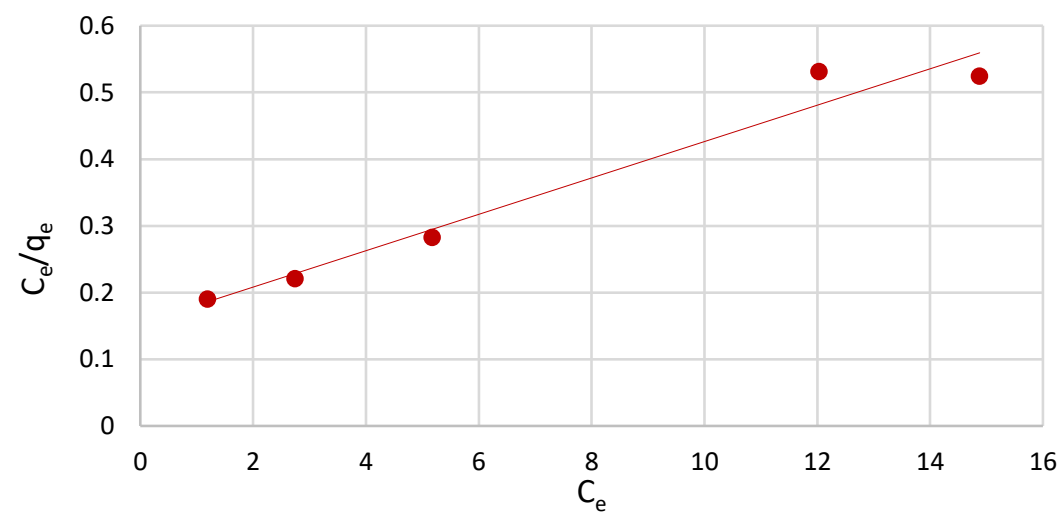

Fig. 11: (a) Freundlich and (b) Langmuir isotherm models for $\mathrm{Cd}^{2+}$ adsorption.

Table 5 presents the isotherm constants and correlation coefficients of $\mathrm{Cd}^{2+}$ adsorption for the Freundlich and Langmuir isotherm models. The $\mathrm{R}^{2}$ values of the Langmuir and Freundlich isotherm models for $\mathrm{Cd}^{2+}$ adsorption are excellent, explaining that the experimental data are best described by both isotherm models. Therefore, the adsorption 
mechanism of this study agrees with both chemisorption and monolayer adsorption on the surface of magnetic biochar.

Table 5: Freundlich and Langmuir isotherm constants and correlation coefficients for $\mathrm{Cd}^{2+}$ adsorption

\begin{tabular}{cccc}
\hline Freundlich & $\mathbf{1 / n}$ & $\mathbf{K}_{\mathbf{F}}$ & $\mathbf{R}^{\mathbf{2}}$ \\
& 0.5555 & 6.3859 & 0.9593 \\
Langmuir & $\mathbf{Q}_{\max }$ & $\mathbf{K}_{\mathbf{L}}$ & $\mathbf{R}^{\mathbf{2}}$ \\
& 36.6300 & 0.1777 & 0.9647 \\
\hline
\end{tabular}

\section{CONCLUSION}

High yield of magnetic biochar was synthesised from NiO-impregnated sugarcane bagasse via slow pyrolysis for heavy metal removal in aqueous solution. The optimum temperature and time to synthesise high-performance magnetic biochar were $500{ }^{\circ} \mathrm{C}$ at 10 min. High cadmium removal up to $88.47 \%$ was obtained using magnetic biochar. The batch adsorption study was conducted for $\mathrm{Cd}^{2+}$ removal in aqueous solution using magnetic biochar. The experimental data followed the pseudo-second-order model $\left(\mathrm{R}^{2} \approx\right.$ 1) and both Freundlich and Langmuir isotherm models achieved the best fitting of $R^{2} \approx 1$.

For future work, a study on the synthesised NiO-impregnated magnetic biochar can be done on industrial wastewater instead of simulated aqueous solution to determine the removal efficiency of the process. Furthermore, a study considering various biomass sources can be conducted to determine the biomass with high yield of magnetic biochar and high heavy metal removal efficiency because Malaysia has abundant biomass resources, especially agricultural waste.

\section{ACKNOWLEDGEMENT}

The authors would like to thank the International Islamic University Malaysia for funding this research under IIUM Research Acculturation Grant Scheme (IRAGS), IRAGS18-0210022 .

\section{REFERENCES}

[1] Li T, Su X, Yu X, Song H, Zhu Y, Zhang Y. (2018) La (OH) 3-modified magnetic pineapple biochar as novel adsorbents for efficient phosphate removal. Bioresource Technology, 263: 207-213.

[2] Rai PK, Lee SS, Zhang M, Tsang YF, Kim KH. (2019) Heavy metals in food crops: Health risks, fate, mechanisms, and management. Environment International, 125: 365-385.

[3] Reguyal F, Sarmah AK, Gao W. (2017) Synthesis of magnetic biochar from pine sawdust via oxidative hydrolysis of $\mathrm{FeCl}_{2}$ for the removal sulfamethoxazole from aqueous solution. Journal of Hazardous Materials, 321: 868-878.

[4] Hao Z, Wang C, Yan Z, Jiang H, Xu H. (2018) Magnetic particles modification of coconut shell-derived activated carbon and biochar for effective removal of phenol from water. Chemosphere, 211: 962-969.

[5] Wang S, Gao B, Li Y, Creamer AE, He F. (2017) Adsorptive removal of arsenate from aqueous solutions by biochar supported zero-valent iron nanocomposite: batch and continuous flow tests. Journal of Hazardous Materials, 322: 172-181.

[6] Wang B, Jiang YS, Li FY, Yang DY. (2017) Preparation of biochar by simultaneous carbonization, magnetization and activation for norfloxacin removal in water. Bioresource Technology, 233: 159-165. 
[7] Engwa GA, Ferdinand PU, Nwalo FN, Unachukwu MN. (2019) Mechanism and health effects of heavy metal toxicity in humans. Poisoning in the modern world-new tricks for an old dog, 10.

[8] Ferlay J, Colombet M, Soerjomataram I, Mathers C, Parkin DM, Piñeros M., ... \& Bray, F. (2019) Estimating the global cancer incidence and mortality in 2018: GLOBOCAN sources and methods. International Journal of Cancer, 144(8): 1941-1953.

[9] Franken C, Koppen G, Lambrechts N, Govarts E, Bruckers L, Hond ED, Loots I, Nelen V, Sioen I, Nawrot TS, Baeyans W, Larebeke NV, Boonen F, Ooms D, Wevers M, Jacobs G, Covaci A, Schettgen T, Schoeters G. (2017) Environmental exposure to human carcinogens in teenagers and the association with DNA damage. Environmental Research, 152: 165-174.

[10] Kazeminezhad I, Mosivand S. (2017) Elimination of copper and nickel from wastewater by electrooxidation method. Journal of Magnetism and Magnetic Materials, 422: 84-92.

[11] Suto R, Ishimoto C, Chikyu M, Aihara Y, Matsumoto T, Uenishi H, Yasuda T, Fukumoto Y, Waki M. (2017) Anammox biofilm in activated sludge swine wastewater treatment plants. Chemosphere, 167: 300-307.

[12] Naeem M, Mujahid M, Umer A, Ahmad S, Ahmad G, Ali J, ... \& Khalid I. (2019) New trends in removing toxic metals from drinking and wastewater by biomass materials and advanced membrane technologies. J. Bio. Env. Sci, 15(3): 10-17.

[13] Suto R, Ishimoto C, Chikyu M, Aihara Y, Matsumoto T, Uenishi H, Yasuda T, Fukumoto Y, Waki M. (2017) Anammox biofilm in activated sludge swine wastewater treatment plants. Chemosphere, 167: 300-307.

[14] Bani-Melhem K, Al-Shannag M, Alrousan D, Al-Kofahi S, Al-Qodah Z, Al-Kilani MR. (2017) Impact of soluble COD on grey water treatment by electrocoagulation technique. Desalination and Water Treatment, 89: 101-110.

[15] Hom-Diaz A, Jaén-Gil A, Bello-Laserna I, Rodríguez-Mozaz S, Vicent T, Barceló D, Blánquez P. (2017) Performance of a microalgal photobioreactor treating toilet wastewater: pharmaceutically active compound removal and biomass harvesting. Science of the Total Environment, 592: 1-11.

[16] Hülsen T, Barry EM, Lu Y, Puyol D, Keller J, Batstone DJ. (2016) Domestic wastewater treatment with purple phototrophic bacteria using a novel continuous photo anaerobic membrane bioreactor. Water Research, 100: 486-495.

[17] Domingues A, Rosa IC, da Costa JP, Rocha-Santos TA, Gonçalves FJ, Pereira R, Pereira JL. (2020) Potential of the bivalve Corbicula fluminea for the remediation of olive oil wastewaters. Journal of Cleaner Production, 252: 119773.

[18] Joseph L, Jun BM, Flora JR, Park CM, Yoon Y. (2019) Removal of heavy metals from water sources in the developing world using low-cost materials: A review. Chemosphere, 229: 142-159.

[19] Kamzon MA, Abderafi S, Bounahmidi T. (2016) Promising bioethanol processes for developing a biorefinery in the Moroccan sugar industry. International Journal of Hydrogen Energy, 41: 20880-20896.

[20] Barrera I, Amezcua-Allieri MA, Estupiñan L, Martínez T, Aburto J. (2016) Technical and economical evaluation of bioethanol production from lignocellulosic residues in Mexico: Case of sugarcan and blue agave bagasses. Chemical Engineering Research and Design. 107: 91-101.

[21] Zhang Y, Song X, Xu Y, Shen H, Kong X, Xu H. (2019) Utilization of wheat bran for producing activated carbon with high specific surface area via $\mathrm{NaOH}$ activation using industrial furnace. Journal of Cleaner Production, 210: 366-375.

[22] Deng CH, Gong JL, Zeng GM, Niu CG, Niu QY, Zhang W, Liu HY. (2014) Inactivation performance and mechanism of Escherichia coli in aqueous system exposed to iron oxide loaded graphene nanocomposites. Journal of Hazardous Materials, 276: 66-76

[23] Jiang W, Xing Y, Zhang L, Guo X, Lu Y, Yang M, ... \& Wei G. (2021) Polyethyleniminemodified sugarcane bagasse cellulose as an effective adsorbent for removing $\mathrm{Cu}$ (II) from aqueous solution. Journal of Applied Polymer Science, 138(7): 49830.

[24] Reitz JR, Milford FJ, Christy RW. (2008) Foundations of Electromagnetic Theory, 4th edn. Addison-Wesley Publishing Company. 
[25] Foo KY, Hameed BH. (2012) Mesoporous activated carbon from wood sawdust by $\mathrm{K}_{2} \mathrm{CO}_{3}$ activation using microwave heating. Bioresource Technology, 111: 425-432. doi:10.1016/j.biortech.2012.01.141

[26] Zhu T, Chen JS, Lou XW. (2012) Highly efficient removal of organic dyes from waste water using hierarchical $\mathrm{NiO}$ spheres with high surface area. The Journal of Physical Chemistry C, 116(12): 6873-6878. doi:10.1021/jp300224s

[27] Collard FX, Bensakhria A, Drobek M, Volle G, Blin J. (2015) Influence of impregnated iron and nickel on the pyrolysis of cellulose. Biomass and Bioenergy, 52-62.

[28] Chen B, Zhou D, Zhu L. (2008) Transitional adsorption and partition of nonpolar and polar aromatic contaminants by biochars of pine needles with different pyrolytic temperatures. Environ. Sci. Technol., 42: 5137-5143 